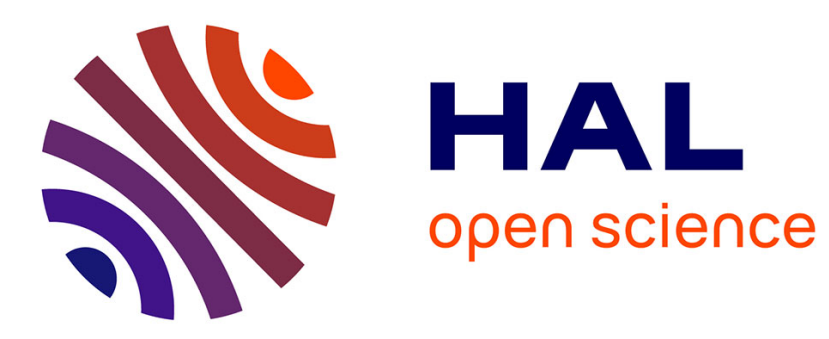

\title{
Could bone tissue be a target for luteinizing hormone/chorionic gonadotropin?
}

Jason P. Mansell, Allen J. Bailey, Jonathan R. Sandy, Sarah J. Yarram

\section{To cite this version:}

Jason P. Mansell, Allen J. Bailey, Jonathan R. Sandy, Sarah J. Yarram. Could bone tissue be a target for luteinizing hormone/chorionic gonadotropin?. Molecular and Cellular Endocrinology, 2007, 269 (1-2), pp.99. 10.1016/j.mce.2006.06.016 . hal-00531898

\section{HAL Id: hal-00531898 https://hal.science/hal-00531898}

Submitted on 4 Nov 2010

HAL is a multi-disciplinary open access archive for the deposit and dissemination of scientific research documents, whether they are published or not. The documents may come from teaching and research institutions in France or abroad, or from public or private research centers.
L'archive ouverte pluridisciplinaire HAL, est destinée au dépôt et à la diffusion de documents scientifiques de niveau recherche, publiés ou non, émanant des établissements d'enseignement et de recherche français ou étrangers, des laboratoires publics ou privés. 


\section{Accepted Manuscript}

Title: Could bone tissue be a target for luteinizing hormone/chorionic gonadotropin?

Authors: Jason P. Mansell, Allen J. Bailey, Jonathan R. Sandy, Sarah J. Yarram

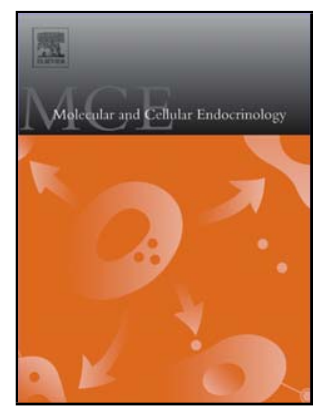

PII:

S0303-7207(07)00049-4

DOI: doi:10.1016/j.mce.2006.06.016

Reference: MCE 6615

To appear in: Molecular and Cellular Endocrinology

Received date: 23-4-2006

Revised date: 23-6-2006

Accepted date: 23-6-2006

Please cite this article as: Mansell, J.P., Bailey, A.J., Sandy, J.R., Yarram, S.J., Could bone tissue be a target for luteinizing hormone/chorionic gonadotropin?, Molecular and Cellular Endocrinology (2007), doi:10.1016/j.mce.2006.06.016

This is a PDF file of an unedited manuscript that has been accepted for publication. As a service to our customers we are providing this early version of the manuscript. The manuscript will undergo copyediting, typesetting, and review of the resulting proof before it is published in its final form. Please note that during the production process errors may be discovered which could affect the content, and all legal disclaimers that apply to the journal pertain. 
Could bone tissue be a target for luteinizing hormone/chorionic gonadotropin?

Jason P Mansell, Allen J Bailey, Jonathan R Sandy, Sarah J Yarram.

Department of Oral \& Dental Sciences, Division of Child Dental Health, University of Bristol Dental School, Lower Maudlin Street, Bristol, BS1 2LY, UK.

\section{Corresponding author}

reprint requests to: $\quad$ Dr Jason P Mansell

Division Child Dental Health

University of Bristol Dental School

Lower Maudlin Street

Bristol, BS1 2LY, UK

Tel: 44-117-928-4779

Fax: 44-117-929-9898

e-mail: j.p.mansell@bris.ac.uk

Key Words: luteinizing hormone, chorionic gonadotropin, bone, osteoblasts.

Abbreviated Title: $\mathrm{LH}$ and the skeleton 


\begin{abstract}
Ovariectomy (OVX) and Zoladex administration to adult rats gave conflicting results with respect to the excretion of total urinary hydroxyproline (OH-Pro), a valuable indicator of bone collagen catabolism. Whereas OVX culminated in early (1 week) increases in OH-Pro, the use of Zoladex actually lowered OH-Pro and showed no sign of increasing over controls for a two-month period. Since both OVX and Zoladex produce a state of estrogen deficiency we reasoned that the differential effects of the two procedures on OH-Pro were attributed to $\mathrm{LH}$ status. Receptors for luteinizing hormone (LH)/human chorionic gonadotropin (hCG) have been identified in many, non-gonadal, estrogen sensitive sites and although bone is receptive to estrogen what effects $\mathrm{LH} / \mathrm{hCG}$ might have upon bone metabolism have received scant attention. Treatment of osteoblasts in culture with a urinary derived formulation of hCG resulted in increased alkaline phosphatase (ALP) activity, raised matrix mettaloproteinase-2 (MMP-2) levels and increased expression of type I collagen. Further studies, using murine calvaria, supported a bone-resorbing effect of hCG. Taken together our initial findings suggested that raised hCG and/or LH might lead to an overall increase in bone matrix turnover as reported for puberty, pregnancy and the menopause. However, when the urinary derived preparation of hCG was replaced with recombinant hormone no changes in osteoblast activity were found implying the presence of contaminating agents in the urine derived hCG. Herein we describe that epidermal growth factor (EGF) could account for the changes observed for urinary derived hCG in osteoblast cultures and that the effects of $\mathrm{LH} / \mathrm{hCG}$ on bone tissue are probably indirect.
\end{abstract}




\section{Introduction}

During an investigation of bone collagen metabolism in response to estrogen deficiency we found that bilateral ovariectomy (OVX) resulted in large increases in total urinary hydroxyproline (OH-Pro). Interestingly the application of the LHRH agonist Zoladex actually lowered OH-Pro. Since both LHRH agonists and OVX result in estrogen deficiency it was tempting to explain the differences observed for $\mathrm{OH}-\mathrm{Pro}$ on LH status. Such a possibility was supported in a subsequent examination of the literature that indicated that receptors for LH were being reported for many estrogen sensitive extragonadal sites (Rao, 2001). Skeletal metabolism undergoes significant changes during puberty, pregnancy and the menopause and although considerable attention has been ascribed to the role played by sex steroids during these periods, the interaction of the gonadotropin hormones, LH and hCG within bone tissue have been overlooked. Chorionic gonadotropin, the natural homologue of $\mathrm{LH}$, is produced by the placenta and represents a major circulating hormone that is present throughout pregnancy. A recent longitudinal study has reported raised skeletal turnover with increasing duration of pregnancy (Black et al., 2000). It has recently been acknowledged that the factors influencing bone metabolism have yet to be identified, particularly those driving bone resorption (Black et al., 2000). During the first trimester the levels of hCG are at their greatest, reaching approximately $1 \mathrm{X} 10^{5} \mathrm{IU} / \mathrm{L}$, at the end of this period the level declines to $1 \times 10^{4} \mathrm{IU} / \mathrm{L}$, and remains unchanged until parturition (Martin et al., 1991). Puberty is also accompanied by marked changes in skeletal growth, an event under the control of local and systemic growth factors that might include LH. Nocturnal surges of LH are known to occur during puberty in both humans (Wennink et al., 1988; Wennink et al., 1990) and non-human primates 
(Terasawa et al., 1984), interestingly it is during these hours that skeletal growth is at its greatest. The menopausal loss of ovarian function and declining levels of estrogen result in a loss of negative feedback on the hypothalamic-pituitary axis, culminating in a demonstrable rise in circulating LH up to ten times the concentration found premenopausally (Goldfien and Monroe, 1991). The menopause is accompanied by striking changes in bone turnover that often result in osteopaenia and an increased risk of developing osteoporotic fractures (Lindsay and Cosman, 1992).

In considering the associated changes in bone metabolism with the presence of elevated $\mathrm{LH} / \mathrm{hCG}$ levels and the differences we observed for $\mathrm{OH}-\mathrm{Pro}$ in response to OVX and Zoladex administration, a search for the LH receptor within bone was warranted. Both $\mathrm{LH}$ and hCG bind to the same receptor, a seven transmembrane domain G-protein coupled receptor (Dufau, 1998) that is assuming a greater global significance in the regulation of tissue metabolism than was once thought. The identification of receptors for LH outside of the ovarian-pituitary axis is relatively recent (Rao, 2001). Interestingly there is a compelling association between LH receptor expression and the sensitivity of the same site to estrogen. Skin, mammary gland, uterus and urinary bladder express LH receptors and respond to changes in estrogen status. Of additional significance is the fact that estrogen can influence LH receptor expression and therefore the sensitivity of target tissues to this gonadotropin as observed, for example, in the epithelial tissue of the pig oviduct (Gawronska et al., 1999). Collectively, these findings imply that LH elicits a diverse array of cell and tissue responses other than ensuring the regulation of gonadal function. 
We therefore sought to determine whether bone tissue and bone forming osteoblasts might also be targets for LH/hCG. Luteinizing hormone and hCG belong to the cystine knot superfamily (Hearn and Gomme 2000), sharing several topological features with other family members known to influence bone tissue metabolism, for example activins and bone morphogenetic proteins. In light of the changes that take place to the skeleton during periods of elevated $\mathrm{LH} / \mathrm{hCG}$ levels combined with the reported effects of estrogen on bone (Tobias and Compston 1999) and the strong association between $\mathrm{LH} / \mathrm{hCG}$ and estrogen, we hypothesized that bone tissue and bone forming osteoblasts might be targets for $\mathrm{LH} / \mathrm{hCG}$. 


\section{Materials and Methods}

2.1 Ovariectomy and LHRH agonist administration. To better reflect the degree of elderly bone tissue catabolism in response to ovarian failure, as would occur postmenopausally, older rats were used. All animals used in this study were retired exbreeder female Sprague-Dawley rats aged 9 months at the time of surgery or LHRH agonist administration. Five animals either underwent bilateral OVX adopting the dorsolateral approach or sham operations under halothane anesthesia. These animals were kept for 8 weeks. Four animals received a depot formulation of the LHRH agonist Goserelin (Zoladex, Zeneca Pharmaceuticals, Macclesfield, Cheshire), under halothane anesthesia. This formulation produces a slow release of Goserelin over 4 weeks (Walker et al., 1984). A second depot was given at the end of week 4. During the course of the study all animals were allowed access to food (conventional rat and mouse maintenance diet, Harlan, UK) and tap water ad libitum. Animals were subject to 12 hour light/dark cycles. At the end of the experiment all animals were sacrificed, their uteri removed and their native weights taken.

2.2 Urinalysis for creatinine and total OH-Pro quantification. In this study, urine samples were collected 24 hours before any surgery or drug administration, once a week for the first month and then twice further in the second and final month of the experiment. Urine collections were made using metabolic cages over a 24 hour period. Following collection, urine samples were decanted into sterile containers (30ml, Greiner) and centrifuged at $8000 \mathrm{rpm}$ for 10 minutes to remove any debris. Creatinine was analyzed on a Beckman autoanalyzer adopting the method of Heinegard and Tiderstrom (1973). Aliquots $(500 \mu l)$ of urine were dispensed into 
polypropylene tubes (6ml Sarstedt Leicester, UK), combined to an equal volume of concentrated $\mathrm{HCl}$ (BDH Analar sp.gr. 1.18) and hydrolyzed for 24 hours at $110^{\circ} \mathrm{C}$. Following hydrolysis, samples were lyophilized, reconstituted with distilled water, centrifuged to remove carbon deposits and appropriately diluted to quantify $\mathrm{OH}-\mathrm{Pro}$. The method adopted involved the use of a continuous flow autoanalyzer (ChemLab Instruments Ltd., Hornchurch, Essex, UK) as previously described (Bannister and Burns 1970). The urine concentration of total $\mathrm{OH}-\mathrm{Pro}$ is expressed as $\mu \mathrm{mols} \mathrm{OH}-$ Pro/mmol creatinine.

\subsection{Maintenance and treatment of human osteoblasts for LH receptor identification by immunolocalization}

The human osteosarcoma derived osteoblast cell line, MG63, were cultured in conventional tissue culture flasks $(250 \mathrm{ml}$, Greiner) in a humidified atmosphere at $37^{\circ} \mathrm{C}$ and $5 \% \mathrm{CO}_{2}$. Cells were grown to confluence in DMEM/F12 nutrient mix (Sigma) supplemented with sodium pyruvate ( $1 \mathrm{mM}$ final concentration), L-glutamine $(4 \mathrm{mM})$, streptomycin $(100 \mathrm{ng} / \mathrm{ml})$, penicillin $(0.1 \mathrm{units} / \mathrm{ml})$ and $10 \% \mathrm{v} / \mathrm{v}$ fetal calf serum (Sigma). The growth media ( $500 \mathrm{ml}$ final volume) was also supplemented with $5 \mathrm{ml}$ of a 100-x stock of non-essential amino acids (Sigma).

Once confluent the cells were passaged into the wells $\left(10^{4}\right.$ cells in $0.5 \mathrm{ml}$ of media/well) of 8 -well chamber slides $\left(\mathrm{Lab}^{-\mathrm{Tek}^{\mathrm{R}}}{ }^{\mathrm{Chamber}}\right.$ slide ${ }^{\mathrm{TM}}$ systems, Nalge Nunc Int.) and subsequently left under conventional cell culture conditions for $16 \mathrm{~h}$, the media and cell chambers removed, and the adherent cells probed for the LH receptor. Briefly, slides were fixed by immersing in $2 \%(\mathrm{w} / \mathrm{v})$ paraformaldehyde $(\mathrm{pH}$ 7.4) for $30 \mathrm{~min}$ at room temperature, followed by incubation for $10 \mathrm{~min}$ at $-20^{\circ} \mathrm{C}$ in methanol. Slides were then rinsed in PBS prior to goat serum (Sigma, Co, UK) 
blocking. A blocking solution was prepared by diluting goat serum (5X) in PBS supplemented with $0.1 \%(\mathrm{w} / \mathrm{v})$ BSA. This blocking solution $(300 \mu \mathrm{l} /$ well) was dispensed into each well and left at room temperature for $1 \mathrm{~h}$. The blocking solution was then discarded and $50 \mu \mathrm{l}$ of the $\mathrm{LH}$ receptor antibody (1:10 dilution with $1 \%(\mathrm{w} / \mathrm{v})$ BSA) added to half of the wells. The remaining (secondary control) wells received the antibody diluent solution alone. For these experiments, we used a rabbit polyclonal antibody (a generous gift from Dr. Patrick Roche, Mayo Clinic) that recognized a specific extracellular sequence, residues 15-38 (Roche and Ryan 1989), of the LH receptor. This antibody has been used to examine LH receptor tissue distribution (Paukku et al., 1998). Following antibody application slides were left at room temperature for $1 \mathrm{~h}$ and then rinsed in PBS. A goat anti-rabbit FITC conjugate (Sigma, Co, UK) was diluted 75-fold in the antibody diluent solution, and 50 $\mu 1$ dispensed into each well and left for $1 \mathrm{~h}$ at room temperature. Slides were rinsed briefly in PBS, and each well was then treated with $25 \mu$ l of a propidium iodide mountant (Vectashield, H-1300, Vecta labs) for nuclear staining and a cover slip (22x50mm, BDH) placed on top. LH receptors were visualized using a Leica DMLB fluorescence microscope. All photographs of labeled cells were taken using ISO 400 provia film, $35 \mathrm{~mm}$ (Fuji).

\subsection{Addressing osteoblast responses to hCG.}

Cells were grown to confluence as described above and subsequently dispensed into collagen coated (Biocoat, Becton Dickinson, UK) 24-well plates such that each well contained $1 \mathrm{ml}$ of a $2.5 \times 10^{4}$ cells $/ \mathrm{ml}$ suspension (as assessed by haemocytometry). Cells were then cultured for $65 \mathrm{~h}$, the media removed and the cells treated with the same medium but lacking serum. After $24 \mathrm{~h}$ the medium was removed and the cells then treated with media containing either $1 \mathrm{X} 10^{5} \mathrm{IU} / \mathrm{L}$ hCG or saline control. For cell 
culture experiments a urinary derived preparation of hCG (uhCG, Pregnyl, Organon) was compared with a recombinant formulation (Ovitrelle, Serono). Human osteoblasts were treated with uhCG, under serum free conditions, for a maximum of 72 hours prior to an assessment of cell number, type I collagen synthesis, MMP-2 expression and ALP activity. In parallel with these experiments an investigation of whether parathormone $(\mathrm{PTH}, 100 \mathrm{nM})$ or calcitriol $(\mathrm{D} 3,100 \mathrm{nM})$ could influence the uhCG responses were also conducted. In a further set of experiments we explored whether some of the responses observed could be blocked by AG1478 (500nM, Calbiochem), an inhibitor of the EGF receptor tyrosine kinase.

\subsection{Cell proliferation}

To ensure that all cell culture supernatants were appropriately diluted prior to further analyses, an assessment of cell number was performed using a combination of the tetrazolium compound (3-(4,5-dimethylthiazol-2-yl)-5-(3-carboxymethoxy-phenyl)-2(4-sulfophenyl)-2H-tetrazolium, inner salt (MTS, Promega, UK) and the electron coupling reagent phenazine methosulphate (PMS, Sigma, UK). Each compound was prepared separately in pre-warmed $\left(37^{\circ} \mathrm{C}\right) \mathrm{PBS}$, allowed to dissolve and then combined so that $1 \mathrm{ml}$ of a $1 \mathrm{mg} / \mathrm{ml}$ solution of PMS was combined to $19 \mathrm{ml}$ of a $2 \mathrm{mg} / \mathrm{ml}$ solution of MTS. The resultant mixture was filtered via $0.2 \mathrm{um}$, and $0.2 \mathrm{ml}$ dispensed into each well. A blank consisted of media alone plus $0.2 \mathrm{ml}$ of the MTS/PMS reagent mixture. Plates were left for $1 \mathrm{~h}$ under conventional culturing conditions. Once incubated, samples $(0.1 \mathrm{ml})$ from each well were dispensed onto a 96 well microtitre plate and the absorbances at $492 \mathrm{~nm}$ read using a multiplate reader. Plates were staggered to ensure that all samples were recovered for 96-well plating 
within 5 minutes to minimise the error introduced during the formation of further formazan product by the cell monolayer.

\subsection{Gelatin gel zymography to determine the levels of MMP-2}

The preparation of polyacrylamide gels co-polymerised with gelatin was identical to that described previously (Mansell and Bailey 1998). Tissue culture supernatants were diluted 2 times in a non-reducing loading buffer and the load volumes adjusted to the values obtained for cell number as described above. Sample loadings were calculated as: the mean OD obtained at 492nm for controls/actual OD obtained for all samples X $10 \mu 1$. In this way, the subsequent areas obtained for the enzyme activity upon clarified gels were normalised to cell number. Developed gels were scanned using an Agfa studiostar flat bed scanner and the resultant images processed in SCION IMAGE software as described previously (Mansell and Bailey 1998).

\subsection{Type I collagen production by osteoblasts}

Cell culture supernatants were appropriately diluted to account for cell number as follows: actual sample OD /mean control OD @ 492nm X 1.4 fold dilution. This calculation ensures that samples with greater cellularity undergo the greater dilution prior to analysis. The subsequent quantification of type I collagen synthesis was quantified using an ELISA (Prolagen-C, Metra Biosytems, UK) which detects the Cterminal propeptide of type I collagen (PICP). The Prolagen-C assay is a sandwich immunoassay in a microtiter plate format using an anti-PICP monoclonal antibody coated to the plate. A rabbit anti-PICP antiserum, a goat anti-rabbit ALP conjugated antibody and p-nitrophenyl phosphate substrate enable quantification of the 
propeptide in tissue culture supernatants. The presence of PICP in cell culture supernatants reflects, stoichiometrically, the synthesis of type I collagen (20). The data are expressed as ng PICP per ml of supernatant.

\subsection{Measurement of alkaline phosphatase (ALP) activity}

The treatment of cells to quantify ALP activity was similar to that described previously (Yarram et al. 2004a). Briefly the remaining MTS/PMS reagent was removed and the monolayers rinsed with $1 \mathrm{ml}$ of $\mathrm{PBS}$, the PBS removed and the monolayers lysed with $0.1 \mathrm{ml}$ of $25 \mathrm{mM}$ sodium carbonate ( $\mathrm{pH} 10.3), 0.1 \%(\mathrm{v} / \mathrm{v})$ Triton $\mathrm{X}-100$. After $2 \mathrm{~min}$ each well was treated with $0.2 \mathrm{ml}$ of $15 \mathrm{mM}$ p-nitrophenyl phosphate (di-tris salt, Sigma, UK) in $250 \mathrm{mM}$ sodium carbonate (pH 10.3), 1.5mM $\mathrm{MgCl}_{2}$. Lysates were then left under conventional cell culturing conditions for $3 \mathrm{~h}$. After the incubation period, $0.1 \mathrm{ml}$ aliquots were transferred to a 96 well microtitre plate and the absorbance read at $405 \mathrm{~nm}$.

\subsection{Bone tissue resorption in response to uhCG}

To study any possible bone resorbing effect of uhCG, $\mathrm{Ca}^{45}$ labeled murine calvaria ( $\mathrm{n}=16$ per test) were incubated with hCG (Pregnyl, Organon UK) or medium controls. The bone resorption assay used has been previously described (Perry et al. 1996). Briefly, calvaria underwent a $72 \mathrm{~h}$ incubation period in the presence of $1 \times 10^{3}$, $1 \mathrm{X} 10^{4}$ or $1 \mathrm{X} 10^{5} \mathrm{IU} / \mathrm{L}$ hCG. Calvaria (n=8) were also incubated in $\mathrm{PGE}_{2}(4 \mu \mathrm{g} / \mathrm{ml})$ as a positive control. At the end of the culture period, calvaria were dissolved in $100 \mu \mathrm{l}$ of $90 \%$ formic acid for $1 \mathrm{~h}$ at $60^{\circ} \mathrm{C}$. The concentration of $\mathrm{Ca}^{45}$ present in the bone hydrolysates and aliquots of the actual incubation medium were determined by liquid 
scintillation counting. The data are expressed as an arbitrary resorption value according to the method of Glant and colleagues (1993).

\subsection{Statistical analyses.}

Data were analyzed using a two-tailed, unpaired Student's t-test without assuming equal variance. For the bone resorption assay a one-way ANOVA with a Dunnett's post test was performed. Differences between groups were considered to be statistically significant at $\mathrm{p}<0.05$. 


\section{Results}

3.1 Bilateral OVX results in elevated OH-Pro excretion whereas injection of the LHRH agonist Zoladex does not

A time course urinalysis for total $\mathrm{OH}-\mathrm{Pro}$ was undertaken to ascertain the overall catabolism of collagen in two oestrogen deficient rat models. The excretion of total OH-Pro between LHRH agonist treated and OVX rats is markedly different (Fig. 1). OVX rats displayed a biphasic pattern of OH-Pro excretion when compared to control animals. Maximal urine concentrations of OH-Pro ( $p<0.005$ versus controls) appeared within the first two weeks after surgery. In weeks 6 and 8 the concentration of OH-Pro between these two groups was similar. Rats treated with the LHRH agonist exhibit a very different pattern of OH-Pro excretion when compared to both control and OVX groups. Of particular significance are the findings of significantly $(\mathrm{p}<0.005)$ lower $\mathrm{OH}-\mathrm{Pro}$ concentrations when compared to control rats at weeks 2,3 and 8. The success of OVX and LHRH agonist treatment in producing a state of estrogen deficiency was supported by the reduction $(\mathrm{p}<0.001)$ in uterine mass of these animals (range: 33-60 mg wet weight) compared to the control group (135-215 mg).

\subsection{Human osteoblasts appear to express the LH receptor}

Cell monolayers were grown in glass chamber slides and probed for the presence of the LH receptor. Fig. 2.1 shows cells exposed to both primary and secondary antibodies and reveals the presence of immunolabelled LH receptors. Fig. 2.2 shows the control when cells were treated with the FITC-conjugated secondary antibody alone. The staining of cell nuclei was achieved using a propidium iodide mountant. 
3.3 The urinary derived formulation of hCG, Pregnyl, generates modest increases in cell number and indices supporting matrix synthesis and cell maturation

Initially MG63 cultures were treated with uhCG (Pregnyl) alone at a final concentration of $1 \times 10^{5}$ IU/L and the cells incubated for 24,48 and $72 \mathrm{~h}$. The supernatants and remaining cell monolayers were subsequently processed to assess any changes in cell number, type I collagen synthesis, MMP-2 synthesis and alkaline phosphatase activity. The findings presented in Table 1 indicate that Pregnyl elicits a weak mitogenic response in osteoblasts. In addition this uhCG preparation also lead to modest increases in latent MMP-2 which reached statistical significance $(\mathrm{p}<0.005)$ at all time points. A typical gelatin gel zymogram of conditioned media harvested after $72 \mathrm{~h}$ of culture (Fig 3) clearly demonstrates increased levels of enzyme following treatment with uhCG. Alkaline phosphatase activity was also significantly increased after treatment with uhCG, and this appeared to increase with time. Enzyme levels were greatest following $72 \mathrm{~h}$, an increase that was approximately $80 \%$ compared to controls $(\mathrm{p}<0.001)$. Type I collagen synthesis was also significantly greater at all time points in the supernatants of uhCG treated cells.

\subsection{Pregnyl induces a modest resorptive response in murine calvarial cultures}

A dose-response $\left(1 \times 10^{3}-1 \times 10^{5} \mathrm{IU} / \mathrm{L}\right)$ of whole, $\mathrm{Ca}^{45}$ labeled bone tissue to uhCG is presented in Fig 4. Calvarial bone tissue responded maximally $(\mathrm{p}<0.01)$ to the highest uhCG concentration followed by a weaker resorptive response at $1 \times 10^{4} \mathrm{IU} / \mathrm{L}$ $(p=0.05)$. The lowest concentration of uhCG failed to elicit a resorptive response under our culturing conditions. 
3.5 Co-stimulation of MG63 cells with Pregnyl and calcitriol results in a synergistic increase in alkaline phosphatase activity

Pregnyl $\left(1 \times 10^{5} \mathrm{IU} / \mathrm{L}\right)$, either alone or in combination with $100 \mathrm{nM}$ PTH resulted in a modest, but statistically significant $(\mathrm{p}<0.01)$ increase in alkaline phosphatase activity. The increase in enzyme activity was very similar for both groups (Fig 5A). In stark contrast, the co-treatment of osteoblasts with D3 (100nM) and Pregnyl generated a very large $(\sim 5$ fold $)$ and synergistic increase in ALP activity $(\mathrm{p}<0.001)$ that was independent of cell number (Fig 5B).

3.6 The maturation of MG63 cells in response to Pregnyl and D3 is blocked by $A G 1478$

Although uhCG was capable of eliciting responses in whole bone tissue explants and isolated osteoblasts the application of recombinant hCG (Ovitrelle, Serono) was without effect. This discrepancy implied the presence of urinary contaminants and one such agent includes EGF. To ascertain whether the response of osteoblasts to D3 and Pregnyl might be attributed to possible EGF contamination MG63 cells were also cotreated treated with AG1478. The findings are clear; whereas Pregnyl and D3 induce large, synergistic increases in ALP activity $(\mathrm{p}<0.001)$ the inclusion of AG1478 (500nM) completely blocked the response (Fig 6). 


\section{Discussion}

Bone tissue undergoes dramatic changes in response to alterations in hormonal status and this is perfectly illustrated post-menopause when bone turnover becomes uncoupled resulting in net tissue losses that can often lead to osteoporosis. During our earlier studies of bone matrix changes in response to estrogen deficiency we utilised two seemingly comparable models namely OVX and LHRH agonist treated (adult) rats. Part of our investigations sought to monitor total collagen catabolism and to this end animals were placed into metabolic cages for 24 hour urine collections immediately prior to endocrine intervention and then weekly for the first month and then at six and eight weeks post treatment. As anticipated the excretion of $\mathrm{OH}-\mathrm{Pro}$ rapidly increased over the control group within the first week of surgery, the level remained elevated for approximately two weeks after which the concentration of $\mathrm{OH}-$ Pro began to fall towards control levels by week eight. To our surprise we found that estrogen deficiency triggered by LHRH agonist administration resulted in a significant suppression of $\mathrm{OH}-\mathrm{Pro}$ between the second and third week of injection. After one month a second depot of the agonist was administered which likewise led to a significant reduction in OH-Pro. Since the difference between OVX and LHRH agonist treated rats is inhibition of LH production in the latter we were enticed by the prospect that the large increases in LH in response to OVX were in some way accountable for the changes in $\mathrm{OH}-\mathrm{Pro}$.

The possibility that bone might be a target for LH was especially important because it would profoundly alter our understanding of the endocrine control of bone matrix metabolism and redirect approaches towards preventing and managing post menopausal osteoporosis. Receptors for LH have been identified in many 
extragonadal sites (Rao 2001), furthermore there is a compelling relationship between LH receptor expression and the sensitivity of the same site to oestrogen (Gawronska et al. 1999) and expression of LH receptors has been linked to changes in oestrogen status in several species (Gawronska et al. 1999; Akazome and Mori 1999; Knecht et al., 1984). Since bone-forming osteoblasts have been found to express receptors for estrogen (Komm et al. 1988, Eriksen et al. 1988) it was also a possibility that these same cells might also express receptors for LH. Using the MG63 osteoblast-like cell line, we initially determined whether these cells expressed the LHR and our findings did support expression, as determined immunocytochemically. Furthermore we also found evidence of LHR presence in osteoblasts by immunoblotting and detection of LHR mRNA using nested RT-PCR and subsequent Southern blotting (Yarram et al. 2003). In light of the OH-Pro data we turned towards a model of bone resorption to ascertain whether hCG, a natural ligand of the LHR (Dufau 1998) could provoke a catabolic response. Utilising $\mathrm{Ca}^{45}$ labelled murine calvaria we established that a urinary derived formulation of hCG (uhCG, Pregnyl) was capable of stimulating $\mathrm{Ca}^{45}$ release into the surrounding medium thereby supporting a bone resorptive response of uhCG.

Although it is generally accepted that the endocrine changes accompanying the menopause lead to net bone tissue losses, the rate of overall bone tissue turnover is actually raised, with evidence of increased type I collagen synthesis and ALP activity (Mansell \& Bailey 2003). Using uhCG at a concentration of 1 X10 $10^{5} \mathrm{IU} / \mathrm{L}$ we found that MG63 osteoblasts underwent a very modest increase in proliferation with concomitant increases in type I collagen synthesis, as supported by raised PICP concentrations, elevated ALP activity and increased MMP-2 expression. Because 
osteoblasts are under a constant barrage of signals we conducted an investigation of potential cross talk between uhCG and the two most significant calciotropic hormones, parathormone (PTH) and calcitriol (D3). These particular experiments clearly indicated that D3 was capable of promoting a demonstrable, synergistic increase in ALP activity when used in combination with uhCG, suggesting that this agent pairing actually fuelled osteoblast maturation.

The findings generated using uhCG had to be replicated using recombinant hCG (rhCG) because of the growing number of studies reporting the presence of extraneous contaminating products in urinary derived hormone preparations (Knox et al, 1978; Rolfe et al, 1983; Hofmann et al, 1989; Daja et al, 1993; Morse et al, 1998; Kauffman et al, 1999). Ovitrelle (rhCG) was subsequently applied to MG63 cultures and to our alarm we found that the recombinant hormone was without influence on our cell cultures. It seemed likely therefore that the uhCG harboured a contaminant. Our suspicions were confirmed by incubating reconstituted uhCG with immobilised concanavalin A to bind hCG yet hormone deplete supernatants continued to stimulate osteoblast maturation (data not shown).

We eventually found epidermal growth factor to be a major contributory factor since inclusion of AG1478, an ErbB1 receptor tyrosine kinase inhibitor, completely blocked the large rise in MG63 ALP activity in response to uhCG and D3. Corroboration of EGF contamination in certain formulations of uhCG using an ELISA has since been reported (Yarram et al. 2004b). 
Although earlier indications had hinted at a possible role of LH/CG in osteoblast metabolism the suggestion that these hormones might have a direct influence on bone tissue seemed less likely. In collaboration with Huhtaniemi and colleagues (Yarram et al. 2003) we examined the bone mineral density (BMD) and static histomorphometry on the long bones of LHR knockout (LuRKO) mice, animals that display a profound reduction $(\sim 90 \%)$ in gonadal sex steroid production. In addition to this model we also examined transgenic hCG overexpressing mice (hCG $\alpha \beta+)$ which express supraphysiological levels of hCG. Both models had clear bone phenotypes with LuRKO mice having reduced BMD and the hCG $\alpha \beta+$ mice presenting with much greater BMD compared to wild type controls. However OVX of the hCG $\alpha \beta+$ animals resulted in a return to wild type BMD values clearly indicating an important role of the ovary in stimulating the large increase in bone accrual for the hCG $\alpha \beta+$ mice. Although we suspected estrogen might account for the change in bone mass the circulating levels of this steroid where roughly double that of wild type controls and this level of estrogen is not sufficient to raise BMD to the extent we see ( 40\% increase) in the hCG $\alpha \beta+$ mice. Indeed, Samuels and colleagues (2000) have clearly shown that a circulating level of estrogen at around $100 \mathrm{nM}$, i.e., 500 -fold higher than normal, is required to elicit a similar bone tissue response. It is therefore possible that other ovarian factors, for example activin, inhibin or follistatin, account for the changes observed for the hCG $\alpha \beta+$ mice.

The application of LuRKO and hCG $\alpha \beta+$ mice do indeed support a role of gonadotropins in skeletal growth but their effects on bone are more likely to be indirect. The identities of the additional ovarian agents that precipitate the large increase in BMD could certainly stem from the hCG $\alpha \beta+$ mice and such studies could 
prove to be of considerable value in the generation of alternative treatments for osteoporosis. 


\section{Figure legends:}

Figure 1. Excretion of total hydroxyproline (OH-pro) in two estrogen deficient rat models. At the times indicated, a 24-hour urine specimen was collected. Urine was initially analysed for creatinine and then total $\mathrm{OH}-\mathrm{Pro}$ by acid $(6 \mathrm{M} \mathrm{HCl})$ hydrolysis for 24 hours at $110^{\circ} \mathrm{C}$. The LHRH agonist Zoladex produces a state of estrogen and LH deficiency resulting in a significant decline in total $\mathrm{OH}$-pro at weeks 2,3 and 8 when compared to controls $(\ddagger \mathrm{p}<0.005)$. Bilateral OVX produces a state of estrogen deficiency and elevated $\mathrm{LH}$ resulting in a significant rise in $\mathrm{OH}$-pro compared to sham operated rats for the first two weeks $\left({ }^{*} \mathrm{p}<0.005\right)$. The levels of $\mathrm{OH}$-pro begin to subside over the following two weeks but still remain greater than those of the controls $(\dagger \mathrm{p}<0.05)$. Between weeks 6-8, OVX and controls appear to exhibit a similar pattern of OH-pro excretion.

Figure 2. Immunolocalisation of LH receptors associated with human osteoblasts. Fig 2.1 is the result obtained using both the primary and secondary antibodies. Fig. 2.2 is a secondary antibody control. Nuclear staining was achieved using a propidium iodide containing slide mountant. The primary antibody $(100 \mathrm{x}$ dilute $)$ detects an amino acid sequence (15-38) peculiar to the extracellular domain of the LH receptor. The secondary antibody ( $75 \mathrm{x}$ dilute) is an FITC conjugate enabling $\mathrm{LH}$ receptor identification. 
Figure 3. Human osteoblast latent MMP-2 levels in response to uhCG. Cells were stimulated with uhCG $\left(1 \times 10^{5} \mathrm{IU} / \mathrm{L}\right)$ for 72 hours and the conditioned media harvested for an analysis of latent MMP-2 using gelatin gel zymography. Sample dilutions were adjusted according to the data obtained for cell number and the samples electrophoresed under denaturing conditions. An MMP-2 standard was loaded into lane 1. This standard contains both pro and active MMP-2 together with an additional autolysis product that migrated to a position corresponding to a molecular mass of approximately $45 \mathrm{kDa}$. Lanes 2-7 were loaded with samples obtained from vehicle treated control cultures and the remaining lanes loaded with samples harvested from osteoblasts stimulated with uhCG. Following electrophoresis and overnight incubation in proteolysis buffer, gels were developed as for conventional SDS-PAGE to reveal the proteolytically clarified zones. Confirmation that the observed zones were produced by the actions of MMP-2 was via loss of clarified bands following incubation of gels in buffer supplemented with $10 \mu \mathrm{M}$ BB-3103, a general MMP inhibitor (kindly provided by British Biotechnology).

Figure 4. Bone resorption in response to uhCG. When murine calvariae are treated with uhCG there is a resultant dose dependent increase in bone tissue resorption. The lowest concentration of hCG $\left(1 \times 10^{3} \mathrm{IU} / \mathrm{L}\right)$ failed to generate a resorptive response whereas $1 \times 10^{4} \mathrm{IU} / \mathrm{L}\left({ }^{*} \mathrm{p}=0.05\right)$ and $1 \times 10^{5} \mathrm{IU} / \mathrm{L}$ hCG $\left({ }^{* *} \mathrm{p}<0.01\right)$ did elicit a bone resorptive response. The data presented provide further evidence for $\mathrm{LH}$ receptor functionality in bone tissue. The resorptive value presented is calculated according to the method of Glant et al (17) that takes into account the basal turnover of $\mathrm{Ca}^{45}$ of each calvarium. Results are expressed as a ratio of the induced resorption (IR) divided 
by the basal resorption (BR) of the experimental group versus the IR/BR of the control group. The data are expressed as the mean +/- the SD.

Figure 5. Calcitriol acts synergistically with uhCG in promoting osteoblast maturation whereas PTH is without effect. Although uhCG is capable of stimulating an increase in alkaline phosphatase (ALP) activity $\left({ }^{*} \mathrm{p}<0.01\right)$ the generation of $\mathrm{p}$ nitrophenol (P-NP) from cells exposed to a combination of calcitriol and uhCG is approximately 5 fold greater $\left({ }^{* * *} \mathrm{p}<0.001\right)$. This striking synergistic increase in ALP activity, which is independent of cell number (Fig 5A), reflects greater osteoblast maturation. The co-treatment of osteoblasts with uhCG and PTH did not influence the increase in $\mathrm{P}-\mathrm{NP}\left({ }^{* *} \mathrm{p}<0.01\right)$.

Figure 6. Epidermal growth factor (EGF) is a major contaminant in uhCG.

Osteoblasts undergo a demonstrable maturation response when co-treated with calcitriol and Pregnyl $\left({ }^{*}<0.001\right)$. However, the application of recombinant hCG (Ovitrelle) fails to influence maturation when used in combination with calcitriol (data not shown). These conflicting findings support the presence of contaminants in uhCG and the data presented confirm that one such contaminant includes EGF. The incubation of MG63 cells with uhCG, calcitriol and AG1478, an EGF receptor tyrosine kinase inhibitor, blocked the large increase in alkaline phosphatase (ALP) activity, as supported by reduced p-nitrophenol $(\mathrm{p}-\mathrm{NP})$ production $\left({ }^{* *} \mathrm{p}<0.001\right)$. 
Table 1. The influence of uhCG upon human osteoblast growth, matrix synthesis and maturation. ${ }^{1}$ The reagent combination of MTS/PMS was used to assess cell number; uhCG resulted in a small but significantly greater $\left({ }^{*} \mathrm{p}<0.05\right)$ cellularity compared to vehicle treated wells. Once obtained these data were used to adjust sample dilutions/loadings prior to PICP, alkaline phosphatase (ALP) and MMP-2 levels. ${ }^{2}$ The formation of p-nitrophenol from p-nitrophenylphosphate was measured at $405 \mathrm{~nm}$. After 24 hours there was a modest but statistically significant increase $\left({ }^{* *} p=0.02\right)$ in the absorbance versus controls. The concentration of $\mathrm{p}$-nitrophenol continued to rise signifcantly after $48\left({ }^{* * *} \mathrm{p}<0.001\right)$ and 72 hours $\left({ }^{\theta} \mathrm{p}<0.001\right) .{ }^{3}$ At all time points latent MMP-2 levels were significantly greater than vehicle treated cells by approximately $30 \%\left({ }^{\Psi} \mathrm{p}<0.005\right) .{ }^{4}$ The synthesis of type I collagen on receipt of uhCG, as determined by the quantification of PICP, indicates statistically significant increases at 24, 48 and 72 hours $\left({ }^{\S} \mathrm{p}<0.001\right)$ compared to vehicle treated controls. 


\section{Acknowledgements.}

The authors wish to thank Dr.Patrick Roche of the Mayo Clinic, Rochester,

Minnesota, for the polyclonal antibody used to detect the LH receptor by

immunolocalisation. The authors would also like to thank Dr. Mark Perry,

Department of Anatomy, University of Bristol for his assistance with the bone

resorption assay. Dr. Julian Jenkins kindly provided the recombinant hCG used in this study. Part of this work was funded by a grant awarded from The Sir Samuel Scott of Yews Trust, London. 


\section{References}

Akazome, Y., Mori, T., 1999. Evidence of sex reversal in the gonads of chicken embryos after oestrogen treatment as detected by expression of lutropin receptor. J. Reprod. Fertil. 115, 9-14.

Bannister, D.W., Burns, A.B., 1970. Adaptation of the Bergman and Loxley technique for hydroxyproline determination to the autoanalyzer and its use in determining plasma hydroxyproline in the domestic fowl. Analyst. 95, 596-600.

Black, A.J., Topping, J., Durham, B., Farquharson, R.G., Fraser, W.D., 2000. A detailed assessment of alterations in bone turnover, calcium homeostasis, and bone density in normal pregnancy. JBMR. 15, 557-563.

Daja, M.M., Hiyama, J., Scott, G.K., Renwick, A.G., 1993. The detection and isolation of protease activity associated with purified preparations of human chorionic gonadotrophin. Endo. 132, 1766-1773.

Dufau, M.L., 1998. The luteinizing hormone receptor. Ann. Rev. Physiol. 60, 461496. 
Eriksen, E.F., Colward, D.S., Bery, N.J., Graham, M.L., Mann, K.G., Spelsberg, T.C., Riggs, B.L., 1988. Evidence of oestrogen receptors in normal human osteoblast-like cells. Science. 241,84 .

Gawronska, B., Paukku, T., Huhtaniemi, I., Wasowicz, G., Ziecik, A.J., 1999.

Oestrogen-dependant expression of $\mathrm{LH} / \mathrm{hCG}$ receptors in pig fallopian tube and their role in relaxation of the oviduct. J. Reprod. Fertil. 115, 293-301.

Glant, T.T., Jacobs, J.J., Molnar, G., Shanbhag, A.S., Valyon, M., Galante, J.O., 1993. Bone resorption activity in particulate-stimulated macrophages. JBMR. 8,1071-1079.

Goldfien, A., Monroe, S.E., 1991. Ovaries. In: Greenspan, F.S., ed. Basic and clinical endocrinology. $3^{\text {rd }}$ ed. Connecticut: Appleton \& Lange. 442-490.

Hearn, M.T., Gomme, P.T., 2000. Molecular architecture and biorecognition processes of the cystine knot protein superfamily. Part I. The glycoprotein hormones. J. Molec. Recognit. 13, 223-278.

Heinegard, D., Tiderstrom, G., 1973. Determination of serum creatinine by a direct colourimetric method. Clin. Chem. Acta..43, 305-310.

Hofmann, J., Holzel, F., Hackenberg, R., Schulz, K.D., 1989. Characterization of epidermal growth factor-related protein from human urinary chorionic gonadotrophin. J. Endo. 123, 333-340. 
Kauffman, H.F., Hovenga, H., de Bruijn, H.W., Beintema, J.J., 1999. Eosinophil derived neurotoxin (EDN) levels in commercial human urinary preparations of glycoprotein hormones. Eur. J. Obstet. Gynecol. Reprod. Biol. 82, 111-113.

Knecht, M., Darbon, J.M., Ranta, T., Baukal, A.J., Catt, K.J., 1984. Estrogens enhance the 3',5'-monophosphate-mediated induction of follicle-stimulating hormone and luteinizing hormone receptors in rat granulosa cells. Endo. 115, 41-49.

Knox, G.E., Reynolds, D.W., Cohen, S., Alford, C.A., 1978. Alteration of the growth of cytomegalovirus and herpes simplex virus type 1 by epidermal growth factor, a contaminant of crude human chorionic gonadotropin preparation. J.Clin. Invest. 61, $1635-1644$.

Komm, B.S., Terpening, C.M., Binz, D.J., Graeme, K.A., Gallegos, A., Kurz, M., Greene, G.L., O’Malley, D.W., Haussler, M.R., 1988. Oestrogen binding, receptor mRNA and biologic response in osteoblast-like osteosarcoma cells. Science. 241, 8184.

Lindsay, R., Cosman, F., 1992. Primary osteoporosis. In: Disorders of bone and mineral metabolism. Coe, F.L., Flavus, M.J., eds. New York: Raven Press; 121-150.

Mansell, J.P., Bailey, A.J., 1998. Abnormal cancellous bone collagen metabolism in osteoarthritis. JCI. 101, 1596-1603. 
Mansell, J.P., Bailey, A.J., 2003. Increased metabolism of bone collagen in postmenopausal female osteoporotic femoral heads. Int. J. Biochem. Cell Biol. 35, 522529.

Martin, M.C., Taylor, R.N., Hoffman, P.G., 1991. The endocrinology of pregnancy.In: Greenspan FS, ed. Basic and clinical endocrinology. Connecticut: Appleton \& Lange. 543-568

Morse, J.H., Lustbader, J.W., Harrington, J.W., Canfield, R.E., 1998. Heterogeneity of proteins in commercial preparations of human chorionic gonadotrophin (hCG) demonstrated by western blotting. Am. J.Reprod.Immunol.Microbiol. 17, 134-140.

Paukku, T., Ahtiainen, P., Haavisto, A.M., Huhtaniemi, I.T., 1998. Persistence of biological activity of biotinylated human chorionic gonadotropin and its use for vizualisation of rat luteinizing hormone receptors in tissue sections. J. Histo. Cyto. 46, 993-998.

Perry, M.J., Ponsford, F.M., Mortuza, F.Y., Learmonth, I.D., Atkins, R.M., Elson, C.J., 1996. Osteolytic properties of the synovial-like tissue from aseptically failed joint prostheses. Br. J. Rheumatol. 35, 943-950.

Rao, C.V., 2001. An overview of the past, present, and future of nongonadal LH/hCG actions in reproductive biology and medicine. Sem. Repro. Med. 19, 7-17 
Roche, P.C., Ryan, R.J., 1989. Purification, characterisation and amino-terminal sequencing of rat ovarian receptor for luteinizing hormone/human choriogonadotrophin. J. Biol. Chem. 264, 4636-4641.

Rolfe, B.E., Morton, H., Clarke, F.M., 1983. Early pregnancy factor is an immunosuppressive contaminant of commercial preparations of human chorionic gonadotrophin. Clin. Exp. Immunol. 51, 45-52.

Samuels, A., Perry, M.J., Goodship, A.E., Fraser, W.D., Tobias, J.H., 2000. Is highdose estrogen-induced osteogenesis in the mouse mediated by an estrogen receptor? Bone. 27, 41-46.

Terasawa, E., Bridson, W.E., Nass, T.E., Noonan, J.J., Dierschke, D.J., 1984.

Developmental changes in the luteinizing hormone secretory pattern in peripubertal female rhesus monkeys: comparisons between gonadally intact and ovariectomized animals. Endo. 115, 2233-2240.

Tobias, J.H., Compston, J.E., 1999. Does estrogen stimulate osteoblast function in Postmenopausal women? Bone. 24, 121-124.

Walker K.J., Turkes, A.O., Turkes, A., Zwink, R., Beacock, C., Buck, A.C., Peeling, W.B., Griffiths, K., 1984. Treatment of patients with advanced cancer of the prostate using a slowrelease (depot) of the LHRH agonist ICI 118630 (Zoladex). J. Endo. 103, R1-R4. 
Wennink, J.M., Delemarre-van-de Waal, H.A., Van Kessel, H., Mulder, G.H., Foster, J.P., Schoemaker, J., 1988. Luteinizing hormone secretion patterns in boys at the onset of puberty measured using a highly sensitive immunoradiometric assay. J. Clin. Endo. Metab. 67, 924-928.

Wennink, J.M., Delemarre-van-de Waal, H.A., Schoemaker, R., Schoemaker, H., Schoemaker, J., 1990. Luteinizing hormone and follicle stimulating hormone patterns in girls throughout puberty measured using highly sensitive immunoradiometric assays. Clin. Endo. 33, 333-344.

Yarram, S.J., Perry, M.J., Christopher, T.J., Westby, K., Brown, N.L., Lamminen, T., Rulli, S.B., Zhang, F.-P., Huhtaniemi, I., Sandy, J.R., Mansell, J.P., 2003. Luteinizing hormone receptor knockout (LuRKO) mice and transgenic human chorionic gonadotropin (hCG) overexpressing mice (hCG $\alpha \beta+$ ) have bone phenotypes. Endo. $144,3555-3564$.

a. Yarram, S.J., Tasman, C., Gidley, J., Clare, M., Sandy, J.R., Mansell, J.P., 2004. Epidermal growth factor and calcitriol synergistically induce osteoblast maturation. Mol. Cell. Endo. 220, 9-20.

b. Yarram, S.J., Jenkins, J., Cole, L.A., Brown, N.L., Sandy, J.R., Mansell, J.P., 2004. Epidermal growth factor contamination and concentrations of intact human chorionic gonadotropin in commercial preparations. 82, 232-233. 
Fig 1

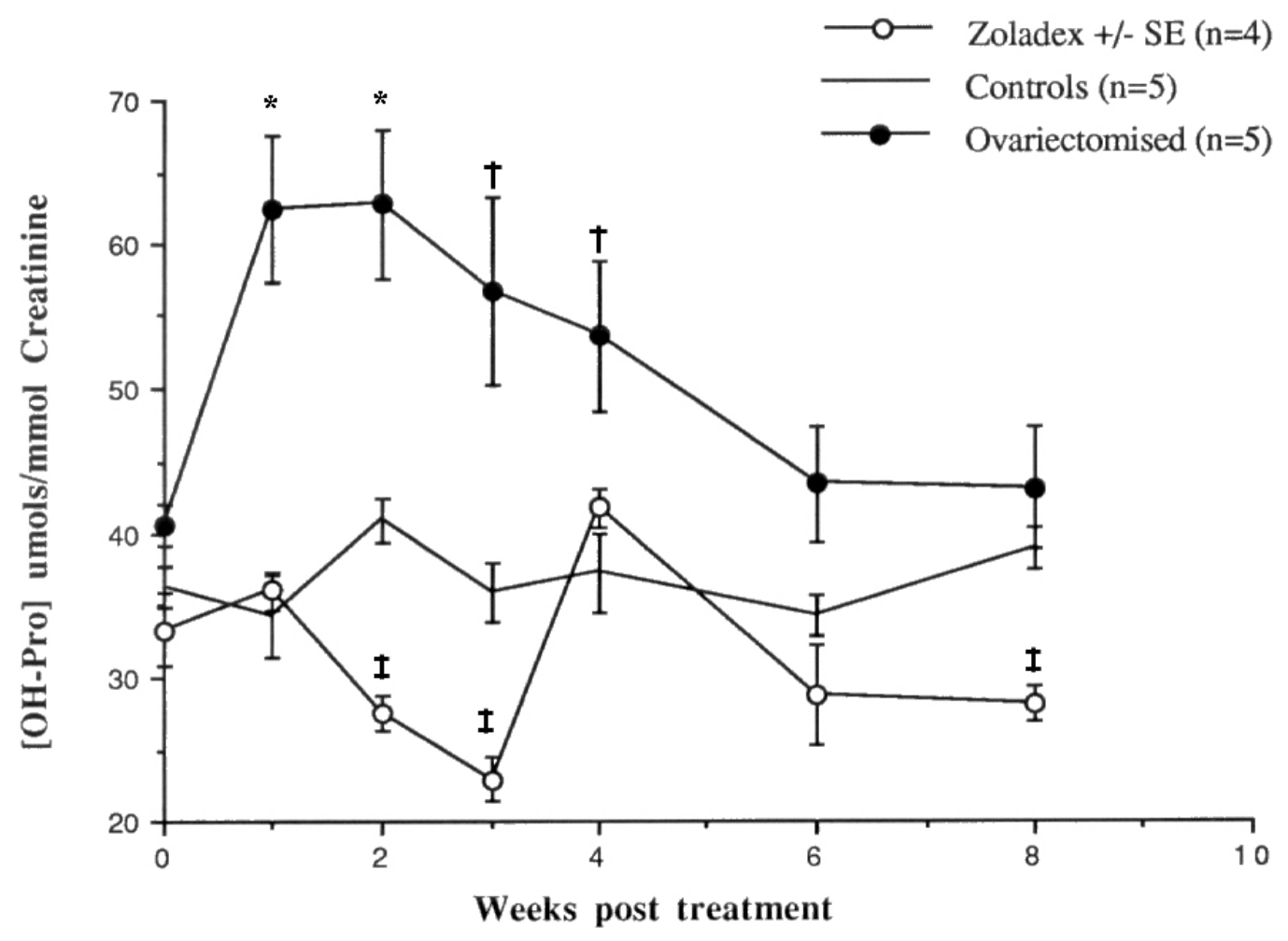


Fig 2.1

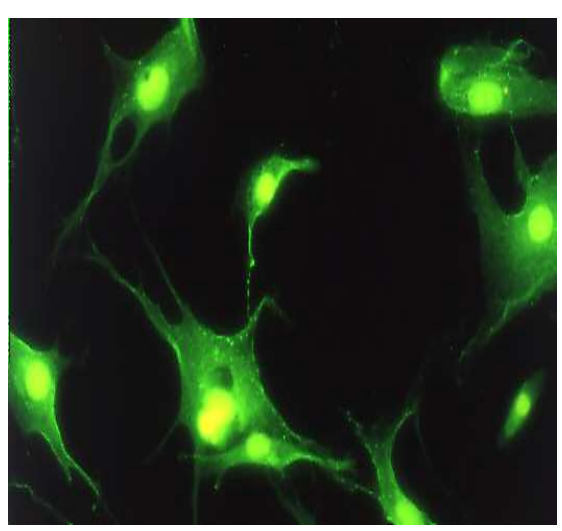

Fig 2.2

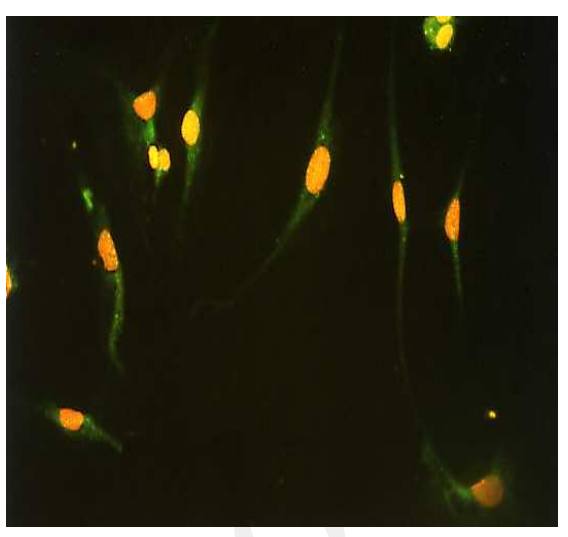


Fig. 3

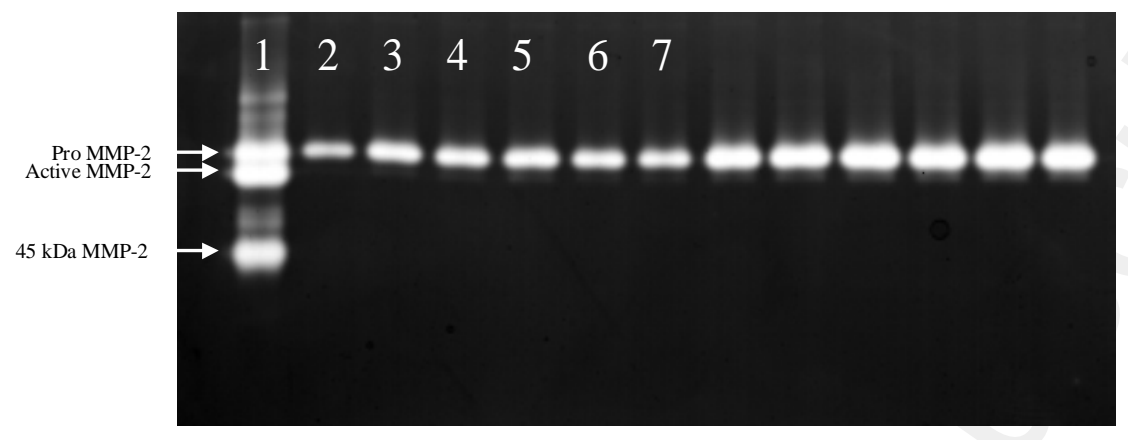


Fig 4

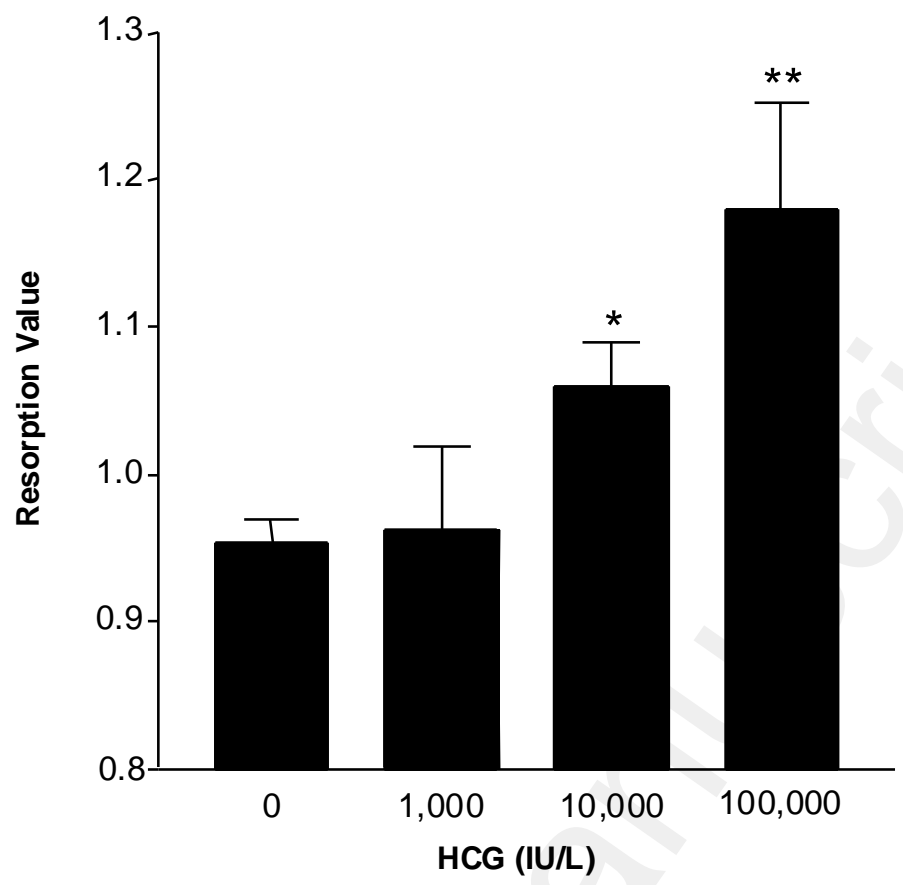


Fig 5
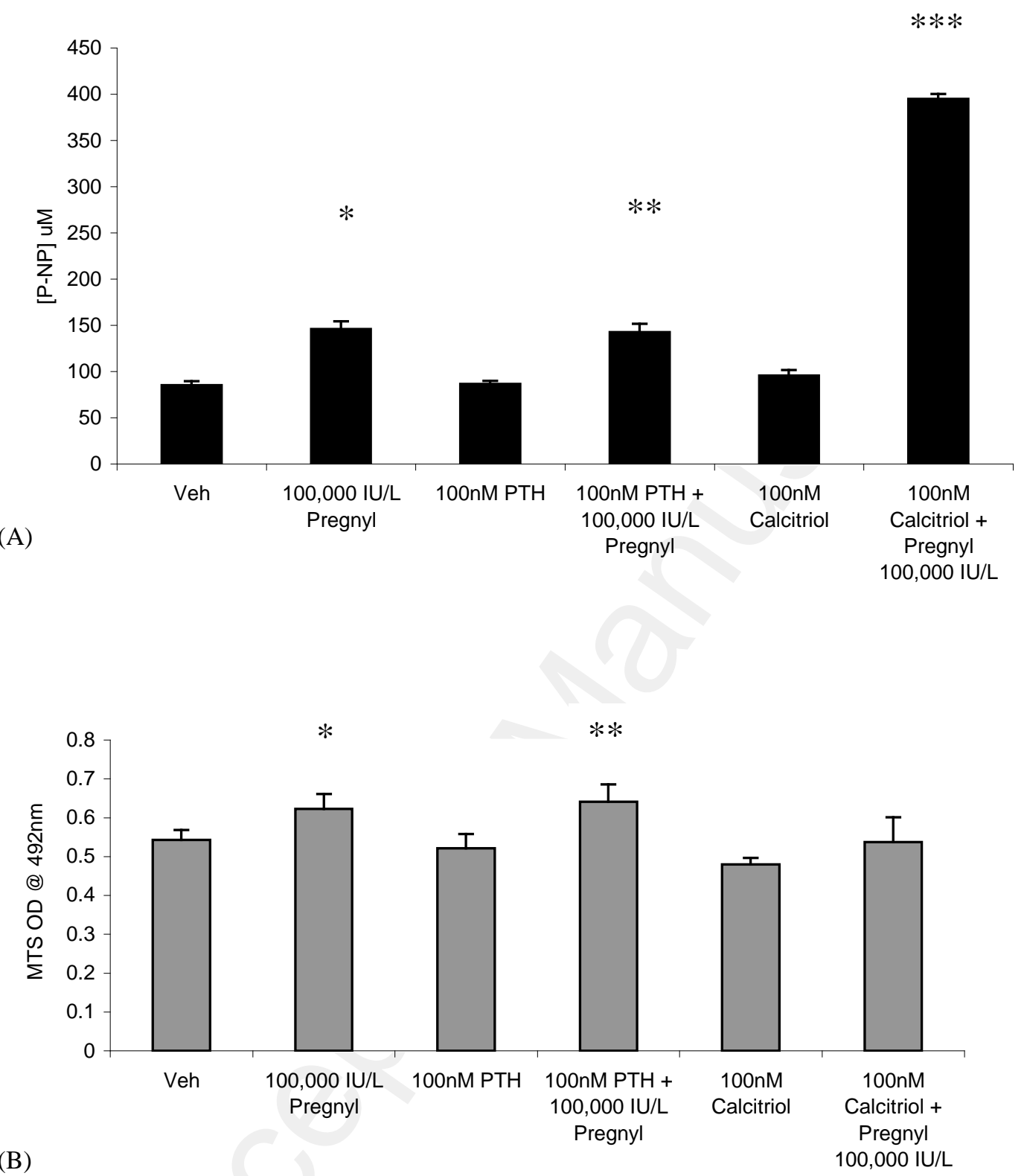
Fig 6

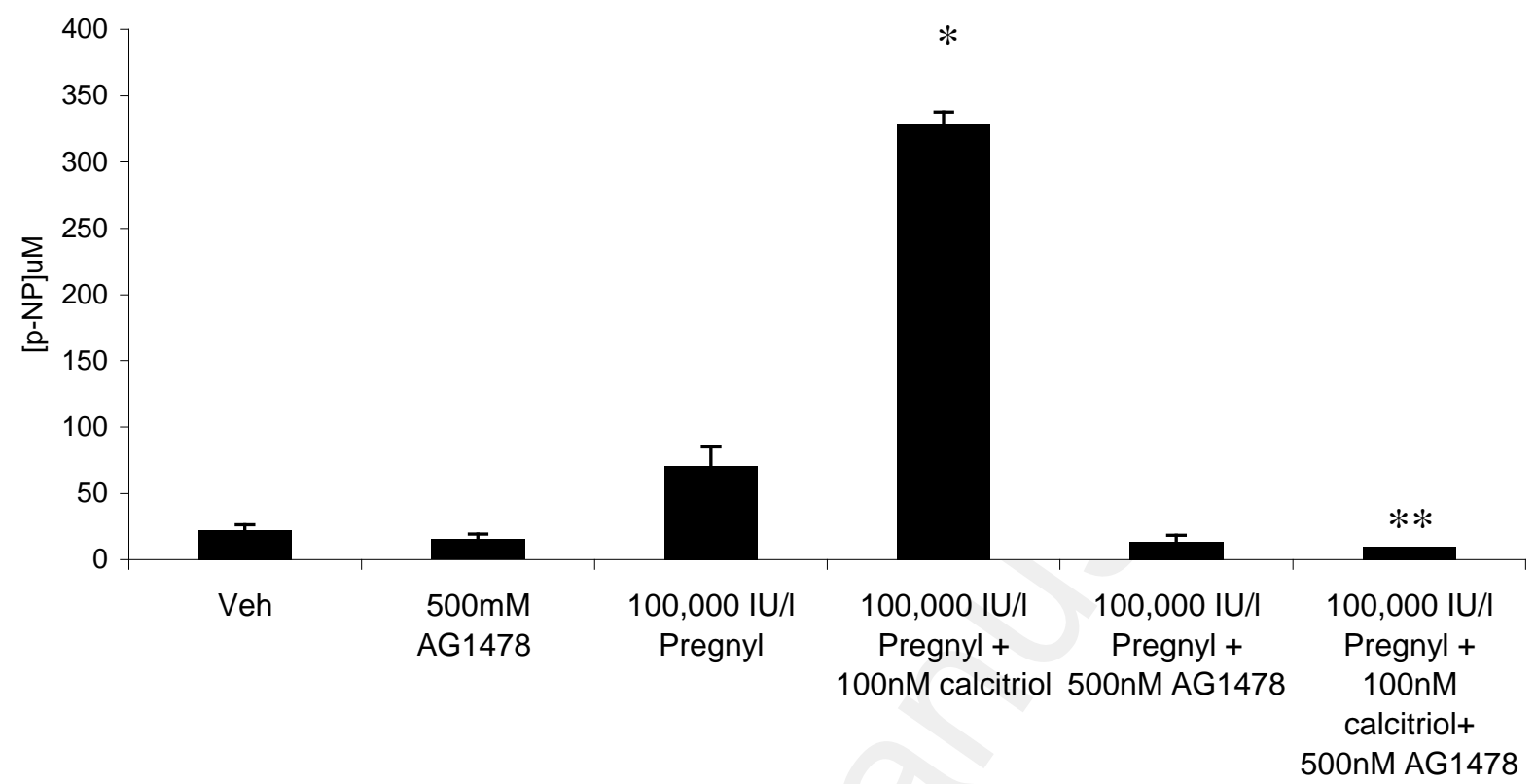


Table 1.

\begin{tabular}{|c|c|c|c|c|}
\hline \multirow[b]{2}{*}{ Group } & \multicolumn{3}{|c|}{ Analyte } & \\
\hline & $\mathrm{MTS} \mathrm{PMS}^{1}$ & Alkaline phosphatase ${ }^{2}$ & MMP- $2^{3}$ & $\mathrm{PICP}(\mathrm{pg} / \mathrm{ml})^{4}$ \\
\hline Vehicle $24 \mathrm{hr}$ & $0.17 \pm 0.01$ & $0.40 \pm 0.03$ & $645 \pm 44$ & $18.6 \pm 2$ \\
\hline HCG & $0.19 \pm 0.02^{*}$ & $0.43 \pm 0.02^{* *}$ & $923 \pm 46^{\psi}$ & $27.7 \pm 2.4^{\S}$ \\
\hline Vehicle $48 \mathrm{hr}$ & $0.15 \pm 0.01$ & $0.42 \pm 0.04$ & $789 \pm 49$ & $19.9 \pm 2.4$ \\
\hline $\mathrm{HCG}$ & $0.17 \pm 0.01^{*}$ & $0.55 \pm 0.04^{* * *}$ & $1007 \pm 101^{\psi}$ & $30.7 \pm 1.6^{\S}$ \\
\hline Vehicle $72 \mathrm{hr}$ & $0.11 \pm 0.01$ & $0.41 \pm 0.05$ & $896 \pm 46$ & $10.4 \pm 2.6$ \\
\hline $\mathrm{HCG}$ & $0.13 \pm 0.02^{*}$ & $0.75 \pm 0.06^{\theta}$ & $1169 \pm 38^{\psi}$ & $22.5 \pm 2.3^{\S}$ \\
\hline
\end{tabular}

